Title

Socio-business responsibility in the Gulf Arab states: The case of the Pearl Initiative

\title{
Introduction
}

Mr. Badr Jafar, as co-founder, launched the Pearl Initiative (PI) in September, 2010.

In a blog entry, he refers to the timeliness of that launch,

as leaders around the world look toward to rebuilding and reinvigorating the fractured global economy, the connection between good governance in the private sector and sustainable economic growth is more apparent than ever before. With a goal to promote a culture of transparency and accountability in the Arabian Gulf region, and across the globe, I'm excited to say that the Pearl Initiative's activities are just getting underway (Jafar, 2010).

The poor state of the global economy had opened up an opportunity to drive change towards business practices for the benefit of society.

Accordingly, Badr Jafar has declared his vision to be a future of blameless corporate governance in private sector companies. The PI will follow that vision through a mission to transform corporate culture into a state of transparency and accountability. The strength of the vision and mission is based on a belief that the PI will introduce new ways of organization for the good of business and society in the long term. But this worthy ambition is set against the business history of a highly competitive private sector in the Arabian Gulf region composed of long standing family businesses and international companies. These are highly focused on business success, but the awareness of business responsibility to society is as yet immature. The founder and employees of the PI are faced with a strategic dilemma as to how best to fulfill the vision and mission within the current context in this region.

\section{The Founder of the Pearl Initiative}


Badr Jafar ${ }^{1}$ is a citizen of the United Arab Emirates ${ }^{2}$ (UAE), a young country that was formed in 1971 from seven separate emirates. Badr gained international experience at a young age as he attended school in the United Kingdom (UK), and then earned business degrees, firstly from Cambridge University (UK), and then Harvard University (USA). Badr was recognized in awards for excellent scholarship, high character and achievements at Harvard, and continues as Chair of the Alumni advisory council at Cambridge. Interestingly, for the son of a prominent UAE family, he did not then join the family business immediately on graduation. Instead, Badr proved himself as an entrepreneur by setting up businesses across a range of industries including fashion, property and private equity.

Badr returned to the UAE to become both president of the family business, Crescent Petroleum, a 40 year old privately owned petroleum and gas company, and also Managing Director of the Crescent Group. He had not only honed his commercial talents overseas, but Badr also has a previous history of entrepreneurship in the Arab region. In partnership with American music legend, Quincy Jones, he has developed business opportunities in film, television and digital work, in the Middle East North Africa (MENA) region. Badr's social activism and philanthropy has also been honored with a CITYarts award for making a difference, and he became the Middle East Philanthropist of the Year in 2013.

\section{The Founding of the Pearl Initiative}

Badr and co-initiator Amir Dossal established the PI in 2010 as a private, not-forprofit organization. Amir Dossal is the founder of the Global Partnership Forum ${ }^{3}$, which is a forum for collaboration on issues of social impact. The initiative was set

\footnotetext{
${ }^{1}$ Badr Jafar, chief protagonist in this case study, is referred to as Badr with his permission.

${ }^{2}$ See further on the history and culture of the UAE at http://www.sheikhmohammed.co.ae

${ }^{3}$ See further about the Global Partnership Forum at http://www.partnerships.org/.
}

2 
up in collaboration with the United Nations Office for Partnerships (UNOP), the latter organization being an endeavor to further the international millennium development goals. The international profile of the PI was raised as its launch took place at the United Nations (UN), where the company reinforced its commitment that GCC companies would "enhance accountability and transparency standards over the next three Years" (UNOP, 2010, para. 1). The PI, through its founder, has raised a call for action in the private sector to be proactive in terms of social accountability.

The original impetus for the PI came from various business owners who considered it was time to raise business standards in the countries of the Cooperation Council for the Arab States of the Gulf (GCC); Bahrain; the Kingdom of Saudi Arabia (KSA); Kuwait; Oman; Qatar; UAE. The PI founder sees himself and like-minded business owners to be making an investment in business that will be a catalyst for improving society,

we are all in a very unique position today, where businesses can do good, while doing well at the same time, which is why we here are all committed and invested in improving the life of the communities we serve and in which we operate (Campden, 2013, para.4).

From that catalyst can possibly grow a GCC regional network of business leaders who are committed to driving joint action and sharing knowledge and experience about business and social issues.

\section{Social Entrepreneurship}

Social Entrepreneurship (SE) is a relatively recent model of business focused on creating social value. These companies can be for profit or not for profit and small, medium or large enterprises. A facet is also that social enterprises need to collaborate with others to solve societal problems. SE is business oriented, but needs to be

\footnotetext{
${ }^{4}$ See further about the GCC at http://www.gcc-sg.org/eng/index.html.
}

3 
innovative in its business strategy to ensure social value is represented in the long term through concern for social, environmental and economic good. To achieve this a social enterprise needs to consider the business motivation, what knowledge it needs and how to measure company outcomes. A global survey on SE is contained in the Global Entrepreneurship Monitor (GEM) through such measures as whether profits are used for the community. Both emerging (developing) and developed (emergent) markets are measured in the GEM, for instance the SE activity of the UAE is $4.93 \%$, and that of the USA (4.15\%) (Griffiths et al., 2013, p.350).

An entrepreneur concentrates on financial value and the efficiency of a business, and this is a relatively new version of business leadership in the Arab world. A reason is a lack of entrepreneurship focus in education, and as yet little concern for SE in the business community. The successful traits for business or social entrepreneurship, are somewhat similar, e.g. ambition and risk-taking, but there may also be differences. One way a social entrepreneur can be recognized is through finding opportunity to add social value through art and this is usually achieved in collaboration with others. Examples of social entrepreneurs are Warren Buffet (USA) and in Bangladesh, Muhanned Younis who gave away their fortune or loaned to the poor. But we can recognize that such people are few and certainly cannot solve the global social problems alone.

A problem for private sector integration in the region has always been the resistance to interference from expatriates, who are considered outsiders to a tight community of locally led businesses. There are many nationalities working in the GCC and these outsiders form that expatriate workforce. In the UAE, for example, there are large numbers of Arabs, Asians, Iranians, and Westerners, with citizens making up less 
than $20 \%$ of the whole population ${ }^{5}$. One of the strengths for the PI is that as a local company it can possibly pull together the whole business community.

\section{Building the Pearl Initiative Organizational Structure}

Following the launch of the PI, the next six months was spent in making decisions about the company reporting structure. The patron of the PI is His Highness Dr. Sheikh Sultan Bin Mohamad Al-Qasimi, who is a member of the Supreme Council of the $U A E$, the Ruler of the Emirate of Sharjah, and he is also the President of the American University of Sharjah. Patronage of businesses by senior figures is usual in the UAE through a system known as wasta, which is similar to social systems in other countries (e.g. the old boys' networks in the USA/UK and guanxi in China). Such networks are notorious for exercising an influence on business practices through personal and professional connections.

The PI organization is steered by the Executive Committee, referred to internally as the ExCom. On this committee sits Imelda Dunlop, Executive Director, together with the two founders. Imelda initiates program ideas to support the company mission, and gives direction for the fulfilment of these through the ExCom. Any plans that are made are then presented at board meetings. The first decision to be made by the ExCom was to appoint members to the board of governors. Subsequently 16 influential business leaders joined the PI board,

the Board of Governors, which comprises business leaders from the Arabian Gulf region who have demonstrated excellence in their fields and within their societies, will provide leadership and management oversight (Pearl Initiative, board of governors, 2013, para.1).

An example of such a business leader is Majid Al Futtaim, whose company became a founding partner in the PI. Majid Al Futtaim Holding is one of the largest developers

\footnotetext{
${ }^{5}$ For more detail on population statistics see the UAE National Bureau of Statistics http://www.uaestatistics.gov.ae/EnglishHome/ReportDetailsEnglish/tabid/121/Default.aspx?ItemId=19 14\&PTID=104\&MenuId $=1$
}

5 
and operators of shopping malls and hypermarkets in the MENA region. Another local company, the Bank of Sharjah, announced in a press release that it too “embraces Pearl Initiative's core values” (Emirates News Agency, 2012, para.1). Well-known and respected international companies, such as Philips, have also joined the PI network.

The board members are all volunteers and are a resource for the PI through their network of other influential people. The Executive Director applauds the board members for the time and effort they put into the work of the PI, and she describes the board collectively as a "fantastic group of visionary thinkers". The board meets every six to ten months to take high-level decisions about the company direction and to discuss macro social issues, such as youth unemployment, job creation and gender equality. As Imelda confirms, these members are often involved in lively debate at the board meetings to ensure the plans of the PI impact positively on GCC business and social development. She pointed out that each of these board members is involved with the PI because of their individual social responsibility, "they are doing it because it's about them giving back to the wider society".

A senior executive from each involved company is invited to join the PI Integration Board to form a unique partnership between commercial corporations across all industries. Engaging senior people together in this board stimulates discussion on best business practices. The first meeting of the Integration Board was held at the American University of Sharjah, where the PI offices are based in the School of Business Administration. Sharjah is one of the larger emirates in the UAE and the University is considered to be a leading institution ${ }^{6}$. Siting their offices and holding board meetings at a university is symbolic of the PI's involvement with the business

\footnotetext{
${ }^{6}$ For further information see $\underline{w w w . a u s . e d u}$
} 
environment of the future. The PI is based in Sharjah, but to a great extent works outside the country, as Imelda Dunlop mentioned, in 2013 the PI ran more programs in the other GCC countries than in its home base of the UAE.

\section{The Work of the Pearl Initiative}

It was envisioned that an initially small group of businesses could begin to raise awareness and spread best business practices within a few targeted areas. Thus the PI incorporates six vital business areas in its work,

1. Anti-bribery and corruption

2. Corporate governance, particularly in family firms

3. Corporate reporting

4. Women in Leadership

5. Integrity through the supply chain

6. Socially responsible investing

It is towards achievement in these six areas that all the PI program streams are targeted. In this case study we concentrate on items 1-4.

\section{Anti-bribery and corruption}

There is requirement for international standards of business ethics to be followed in a global business environment. A challenge in the Arab region is to progress old business practices towards an increase in standards for the prevention of bribery and corruption. All of the six GCC countries have ratified the United Nations Convention against Corruption ${ }^{7}$, with the Kingdom of Saudi Arabia (KSA) being the latest to join in April, 2013. Imelda Dunlop, as spokesperson for the PI, gave an interview to the TradeArabia News Service (2013), where she links the PI and its partners in a drive to fight corruption,

this partnership is about using our knowledge of the region and experience of driving awareness of the benefits of best practice to reinforce positive regional experiences, and encourage more companies to raise business

\footnotetext{
${ }^{7}$ For more detail on the convention see http://www.unodc.org/unodc/en/treaties/CAC/signatories.html
} 
standards and fight corruption (para. 9).

To raise greater awareness among corporate leaders, the PI convenes occasions for business and other leaders to engage in dialog about business challenges.

These leaders come from both the senior executive and operational levels and meet together at PI organized forums and seminars. For example, two years ago, the KSA National Anti-Corruption Commission (Nazaha) was set up as an independently funded operation that reports directly to King Abdullah Bin Abdulaziz ${ }^{8}$. The PI collaborates with Nazaha, and their joint work on anti-corruption resulted in the first KSA business forum on the topic. 16 business forums have now been held in cities across all the GCC countries to implement business community building through interactive roundtables. Open discussion about such business challenges was previously unknown, due to the secrecy and competition that creates a complex business relationship between GCC leaders. The PI board of governors heralds these roundtable consultations as a major achievement, according to Imelda Dunlop. It is early days, as yet, to speculate on the changes wrought through these forums on antibribery and corruption. Furthermore, it will be difficult to measure the success of such possible changes.

\section{Corporate governance and reporting}

The mission of the PI is to promote best practices in corporate governance by "addressing the globally applicable issues related to a paradigm of corporate accountability" (Chall et al., 2010, p. 487). It is against a backdrop of economic problems in the GCC, where perhaps the PI's strategy for transparent and accountable corporate governance can find some traction. Accordingly, in 2013 the

\footnotetext{
${ }^{8}$ For further details about the KSA see http://www.saudiembassy.net/about/KingAbdullah.aspx
} 
PI launched the first in a series of reports, entitled Accountability and Transparency, bringing attention to positive aspects of corporate reporting. Transparency and accountability is about ensuring that stakeholders are fully aware of what a company is doing, and that an organization is held responsible for any negative impact on business and society.

Accountability and transparency are elements that contribute to Corporate Social Responsibility (CSR). As Imelda pointed out, CSR needs to be fundamental and integral to business process, and, therefore, not just a strategy to be "bolted on". Furthermore, as stated by board member, Jamal Fakhro Managing Partner, KPMG Bahrain/Qatar,

the Pearl Initiative will help create a culture of accountability and transparency and provides a platform for private sector partners to develop and be recognised for their achievements in corporate social responsibility (Abraaj Group, 2011).

There is a CSR policy known as Integrated Thinking, which is about applying the true cost of all resources to financial decision-making, and that is aptly summed up in a statement from Badr,

you can't really tell when you look at a company's statements the net impact of that company on society, whether that company is polluting waters where they have the factory to make the products or if they're using unethical labour practices. So the level of due diligence is much more intense (Badih, 2012, para. 5).

Here is acknowledged the scarcity of water in the GCC, and yet that vital resource is underpriced relative to its value for the region. Thus, integrated thinking is about companies taking a long-term view of their business for a sustainable future for society. However, the framework for integrated reporting has only just been released worldwide, and it lacks compliance measures to enforce it. It is such a new concept that as yet there is no company in the world that produces a truly integrated report. The PI has, therefore, partnered with the International Research Institute in 
Sustainability (IRIS), and the Institute for Sustainability ${ }^{9}$ to help raise awareness about integrated thinking and reporting in the GCC.

As has been said, family led firms are very important in the Gulf Arab states, but there is much less transparency amongst these businesses than in the publicly listed companies. A barrier to reporting is the tradition of rivalry that maintains privacy about business information. The tradition of complete privacy in family companies manifests as a resistance to what is formally termed disclosure in corporate reporting. In today's global business climate there are heightened expectations of corporate reporting from clients and community. In the West, a majority argues for full disclosure in business reporting, but, as the social and economic situation is different in the Middle East, such a practice cannot just be copied and pasted into that business environment.

A problem that stems from a lack of reporting in the GCC is that very little data exists about a large segment of companies. Therefore, one of the first tasks for the PI was to collect intelligence and, together with Price Waterhouse Cooper $(P w C)$, PI surveyed over 100 family heads in each country to gain a snapshot of GCC family businesses. The survey shows that GCC family firms are becoming more aware of the increasing importance of corporate governance, but it is still not a high strategic priority.

\section{Figure 1. Disclosure by GCC family firms - goes here}

Only $17 \%$ of the family firms that were surveyed saw any business need for disclosure. A report entitled, Family matters: Governance practices in GCC family firms ${ }^{10}$ was subsequently published, and is now freely available as a research

\footnotetext{
${ }^{9}$ International Research Institute in Sustainability available at http://insight.glos.ac.uk/sustainability/iris/Pages/default.aspx

${ }^{10}$ Family matters: Governance Practices in GCC Family Firms is available at http://www.pearlinitiative.org/published-research-reports.html
}

10 
resource on the world-wide-web.

The PI is not attempting to change the governance of family firms towards full disclosure, but instead is working towards appropriate disclosure. The Abraaj Group is a member of the PI network, and as a family firm is leading the way in corporate governance and reporting. That company is in transition towards public reporting in setting a worthy example through strategic private reporting. When they buy companies, the Group consider the biggest lever to improving effectiveness is through integrating the company economically, environmentally and socially. Abraaj, measures its spend on societal issues by targeting 5\% of its net management fees for strategic philanthropic programs (Balakrishnan \& Michael, 2011).

The PI message to family firms is about organizing their transition to this standard through communicating effectively with the wider family as stakeholders. In sending such messages now, the aim is for succession plans to be put in place to effect corporate governance in a third or fourth generation of family business owners.

\section{Women in Leadership}

The principle of empowerment for women is a feature of a partnership between the PI and the UN. The proposed outcome is to deliver meaningful insights on what a business needs to do in order to advance women. An international entity such as the $\mathrm{UN}$ is too large to gain much operational traction on the ground of any particular country. Therefore, a strategic partnership was formed between the PI and the United Nations Global Compact ${ }^{11}$ to collaborate on programs to establish responsible business practices in MENA companies. The UN Global Compact is the world's

\footnotetext{
11 See about the UN Global Compact at http://www.pearlinitiative.org/past-events/articles/pearlinitiative-and-un-global-compact-partnership-to-bring-corporate-responsibility-principles-to-the-arabworld.html
} 
largest corporate sustainability initiative with 8,000 business participants in 145 countries. Never before has the UN found such an operation as the PI in this region, and as such the PI has become an essential UN resource through this partnership.

The low numbers of women in the workforce continues to be an issue in the Middle East; the World Bank (2007) estimated a relatively low female labor force participation rate of $31 \%$ for the MENA region. The World Economic Forum (2013) has tracked gender-based disparities since 2006, based on benchmarks including economic participation. In figure 2 is shown the rankings for MENA countries as compiled by the UN (2011, p.1).

\section{Figure 2 Gender Gap Index - MENA - goes here}

Gender equality is a significant influence on SE activity and is affected by the number of women who work. But a continuing global issue is there are few women who own businesses.

The PI raises awareness of the need for increased economic participation by women through forums organized for women only and for both women and men. It argues that there is more than just a moral argument to gender equity in the workforce; there is also the economic consideration. Increased female participation in the work force leads to more diverse human resources to deploy for business success. Furthermore, gender diversity is a business and societal issue, as without diversity there is a risk of poor leadership, and of being out of touch with customers and other stakeholders.

One of the first projects, between the PI/UN Compact and a UAE women's association, was a research project on women's progression. A confidential on-line survey was prepared with the aim of getting 1,000 responses from women of all nationalities in management and senior management roles. The survey's purpose is to find out about "the experiences, challenges, influences and perceptions affecting 
women's career progression” (pers. communication, July 2014). Never before has such a survey been attempted in the GCC. Following the results of the survey the PI will publish a report to communicate what business and society needs to do to support women's progress. The ambitious research project “aims to inform business leaders across the GCC on practical programs to retain and develop more women into senior positions, and thereby create a larger pool of Board-ready women" (pers. communication, July 2014).

Although the PI itself has an all-female workforce, it is noticeable from the website photographs there are no women board members. The company, however, strives to be a role model for women's empowerment and has invited at least six women onto board membership, but as yet there have been no acceptances. As Imelda explained, there are few women with the experience to serve at the level of non-executive director, and consequently those that have such experience are thinly stretched amongst many companies who want their expertise. According to research on UAE private companies with $>300$ employees there were only 62 female board members (2.3\%) (Kemp, Madsen \& El-Saidi, 2013). The PI persists in a resolve to get women on the board, having set itself a target of attracting at least three high-level female leaders. All the board members believe it is their individual responsibility to make this happen by the next board meeting in April, 2014. But how to ensure a gender mix in the boardroom is a reality that is a continuing problem for the PI and other companies.

The Pearl Initiative as a Knowledge Center

The PI knowledge center is regionally focused, offering research-based insight, expert opinion and thought leadership. As an online resource it gives information, website links, is a forum for ideas exchange and guidelines, and offers tools to sustain 
effective business practices. Imelda anticipates that this bilingual resource and information center will become the "Go To" place for any organization in the GCC to find out what others are doing.

The PI gains data and shares knowledge about the GCC business world through building a library of case studies; a process of collective learning that is especially pertinent for the region as there are few such studies currently in existence. The Pearl Initiative Student Case Study Competition, Saudi Arabia ${ }^{12}$ contains the best five university student-authored cases in that country. These cases studies particularly highlight the implementation of integrity related policies. The cases are written in business friendly language to showcase companies that are successfully on the path towards transparency and accountability through integrated reporting. As such, these cases are the start of a library of best practices for other companies to emulate. An extension to this student competition will include a roll out to the UAE and Oman in spring, 2014.

In the PI business plan for 2014, there will be a massive revamp of their online, resource and information center. Supplementing the case studies will also be tools and tips for good governance for business managers to learn from each other. Developing a library of knowledge about corporate good practice within the region is important. Such initiatives influence the thinking of business leaders on what can be achieved in the GCC.

\section{A New Business Model in Context}

The Arab region experienced the Arab Spring only a few years ago, and this raised awareness about potential new models of partnership and consensus between citizens and government. The organizational model that the PI has invoked is that of

\footnotetext{
${ }^{12}$ Available at http://www.pearlinitiative.org/published-research reports.html
} 
partnership between private organizations in the region, "we are for business by business, driven from the region out to the region" (Imelda Dunlop). The PI is firmly private sector focused, but also engages with the public sector in recognition that no one sector (public, private) will be able to address business, economic and societal needs alone.

Any initiative for private sector company leaders has to be based on the business benefits that will emanate from any societal initiative they are partners to. Such a focus is echoed in the words of Imelda Dunlop who stated, "the PI is not a charity, there have got to be win-win outcomes that are good for business and good for society". But as the following figure reveals, the average percentage of pre-tax profit spent on social programs is very low across industries (Fig 1).

Figure 3 Social investment budgets by industry sector - goes here

Over the long term perhaps there are win-win outcomes for business and society in social investment, but a causal link will be difficult to prove.

To grow the sector and remain competitive, private business can no longer assume that government alone can solve societal problems. However, the Initiative deliberately does not seek any government funding, to avoid subservience to a particular governmental agenda. As such, the PI aims to be constructive in supporting civil society by not lobbying or being threatened by any other body, or indeed being seen as a threat by local businesses. Instead, the PI currently funds its own programs and the partner companies commit to an annual cost contribution for funding PI activities. The Initiative leads the way as a recently formed organization that crosses country borders, itself a strategy that adds complexity. The PI works with other companies along the lines of a collective, through collaboration about what business principles will help to solve problems in society. However, despite the best efforts of 
the PI, there may be difficulties in challenging an existent strong culture that is at the heart of GCC family businesses. It is a new organizational model and a concern is that as a new model how far it will be sustainable over the long term.

\section{Conclusion}

The PI partnership model is unique because of many factors. Partnering with global organizations, such as the UN Global Compact and the UN Office for Partnerships, pulls in global best practices to the region. In doing so, the PI makes all programs locally and regionally relevant because the organization is from within the Gulf Arab states and is a resource for the MENA region. There is a partnership with a university to produce business leaders of tomorrow. The knowledge center acts as a catalyst to spur more sharing of desirable business practice from within this region. All the PI programs are aimed at achieving a higher quality of business to benefit society in the future.

It is anticipated that the PI alliance of companies will grow and drive programs such as student competitions, awards, and industry and topic task forces, to impact and change the business behavior of the wider business community in the Gulf Arab states. The PI mission to raise standards in the private sector will also impact on the wider Arab world. That mission also contains a message that is significant for the entire emerging and emergent business world. As Imelda emphasizes, "I would love to see other social entrepreneurship initiatives learning from this model and finding ways to replicate it in other parts of the world". However, for the foreseeable future the PI will continue to focus on private sector business to increase socio-business responsibility within GCC countries. The PI is a network of private sector businesses working together for the success of those same businesses. As a new business model 
the PI proactively drives progress towards raising corporate standards because it makes sense for the future of both business and society. 


\section{References}

Abraaj Group. (May, 16 2011), "Business leaders join forces to promote corporate governance and accountability, Press Article, available at http://www.abraaj.com/news-and-insight/news/press-article-business-leaders-joinforces-to-promote-corporate-governance

American University of Sharjah. (2013), "Music legend Quincy Jones visits AUS", Latest News, available at http://www.aus.edu/news/article/582/music legend quincy jones visits aus

Badih, S. (May 4, 2012), "Pearl Initiative hopes to improve corporate transparency", GulfNews.com, available at http://gulfnews.com/business/general/pearl-initiativehopes-to-improve-corporate-transparency-1.1017974

Balakrishnan, MS and Michael, I. (2011), “Abraaj Capital Limited: Celebration of Entrepreneurship (CoE)", Emerald Emerging Markets Case Studies, vol. 1 no. 4, pp. $1-21$.

Campden. (2013), Middle East Philanthropy Awards, available at http://www.campdenfb.com/content/campden-middle-east-philanthropy-awards

Chell, E, Nicolopoulou, K \& Karataş-Özkan, M. (2010), "Social entrepreneurship and enterprise: International and innovation perspectives", Entrepreneurship \& Regional Development, vol. 22, no. 6, pp. 485-493.

Cooperation Council for the Arab States of the Gulf. (2012), "Homepage", available at http://www.gcc-sg.org/eng/index.html

Emirates News Agency. (18 Mar 2012), "Bank of Sharjah embraces Pearl Initiative's core values", available at http://www.wam.org.ae/servlet/Satellite?c=WamLocEnews\&cid=1289998082362\&p agename $=$ WAM $\% 2$ FWamLocEnews $\% 2 F W A M \_E \_$ArticleMailClient\&parent $=$Colle ction\&parentid $=1135099399948$

Global Partnerships Forum. (2010), "Homepage”, available at http://www.partnerships.org

Griffiths, MD, Gundry, LK \& Kickul, JR. (2013), "The socio-political, economic, and cultural determinants of social entrepreneurship activity: An empirical examination", Journal of Small Business and Enterprise Development, vol. 20, no. 2, pp. 341-357.

His Highness Sheikh Mohammed Bin Rashid Al Maktoum (2013), "Homepage", available at http://www.sheikhmohammed.co.ae

International Research Institute in Sustainability. (2013), "Homepage", available at http://insight.glos.ac.uk/sustainability/iris/Pages/default.aspx 
Jafar, B. (2010), "Welcome to the Pearl Initiative", Blog Entry, September 15, available at http://www.pearlinitiative.org/blog.html

Kemp, LJ, Madsen, S \& El-Saidi, M. (2013), “The current state of female leadership in the United Arab Emirates", Journal of Global Responsibility, vol 4, no. 1, pp. 99112.

KPMG International. (2014), "Sustainable Insight Unlocking the value of social investment", available at

http://www.kpmg.com/Global/en/IssuesAndInsights/ArticlesPublications/sustainableinsight/Documents/unlocking-value-social-investment.pdf

Pearl Initiative. (2013), available at www.pearlinitiative.org

Pearl Initiative \& PwC. (Jan., 2013), "Family matters: Governance Practices in GCC Family Firms", available at http://www.pearlinitiative.org/published-researchreports.html

Pearl Initiative. (Nov., 2013), "Pearl Initiative student case study competition in Saudi Arabia", available at http://www.pearlinitiative.org/published-research reports.html

Royal Embassy of Saudi Arabia. (2013), "Homepage", available at http://www.saudiembassy.net/about/KingAbdullah.aspx

TradeArabia News Service, (2013), Philips joins Pearl transparency initiative [Manama], available at http://www.tradearabia.com/news/MEDIA_244972.html

UAE National Bureau of Statistics. (2010), "Population estimates, 2006-2010, main indicators of labour force, 2008, 2009", available at http://www.uaestatistics.gov.ae/EnglishHome/ReportDetailsEnglish/tabid/121/Defaul t.aspx?ItemId=1914\&PTID $=104 \&$ MenuId $=1$

United Nations. (2011), "Regional overview for the Middle East and North Africa MENA gender equality profile status of girls and women in the Middle East and North Africa", available at http://www.unicef.org/gender/files/REGIONAL-Gender-Eqaulity-Profile-2011.pdf

United Nations Office for Partnerships. (Oct., 4, 2010), "Welcome”, GCC Countries pledge to enhance accountability and transparency standards over the next three years, available at http://www.un.org/partnerships/

UNODC. (2013), "United Nations convention against corruption signature and ratification status as of 29 November 2013, available at http://www.unodc.org/unodc/en/treaties/CAC/signatories.html

World Bank. (2007), “2007 MENA Economic developments and prospects report”, available at http://web.worldbank.org/WBSITE/EXTERNAL/COUNTRIES/MENAEXT/0, conte ntMDK:21297037 pagePK:146736 piPK:146830 theSitePK:256299,00.html 
World Economic Forum. (2013), "Global Gender Gap", available at http://www.weforum.org/issues/global-gender-gap 
Linzi J. Kemp, Imelda Dunlop, "Socio-business responsibility in the Gulf Arab states: the case of the Pearl Initiative",

Emerald Emerging Markets Case Studies, (2014),

https://doi.org/10.1108/EEMCS-01-2014-0018

Socio-business responsibility in the Gulf Arab states: The case of the Pearl Initiative

Figure 1. Disclosure by GCC family firms

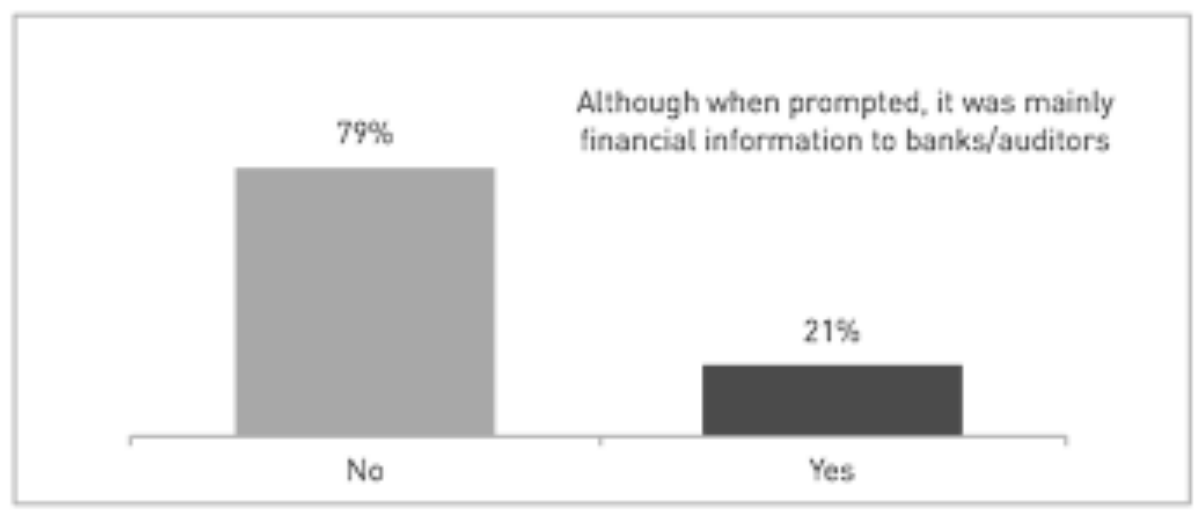

Figure 13: Do you disclose any financial information publicly?

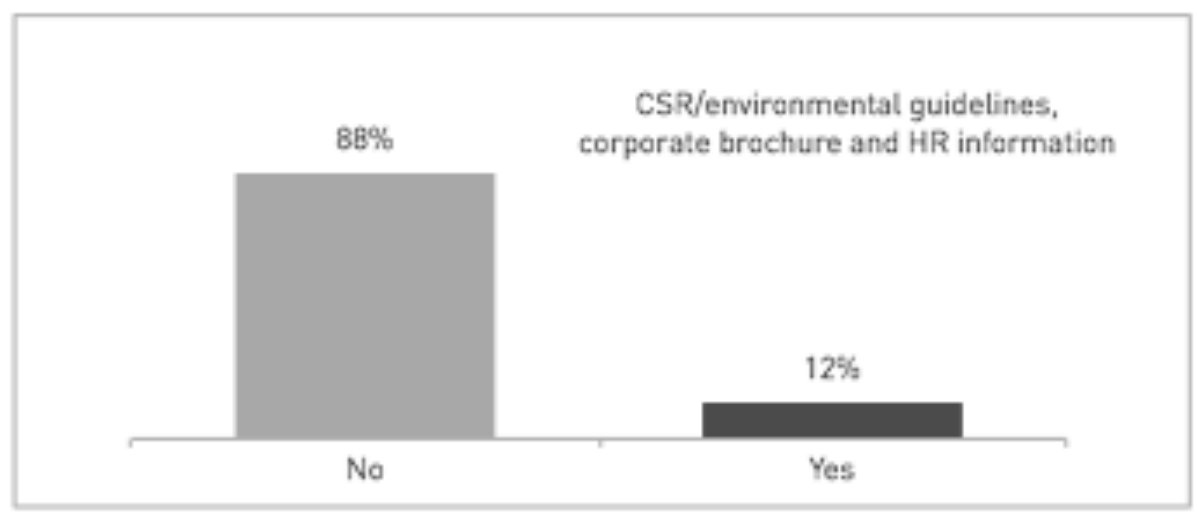

Figure 14: Do you disclose non-financial,

environmental, social or govemance information?

(Pearl Initiative and PwC, Jan., 2013, p.21). 
Figure 2 Gender Gap Index - MENA

\begin{tabular}{|l|l|l|}
\hline \multicolumn{2}{|l|}{ Gender Gap Index 2010} & \\
\hline $\begin{array}{l}\text { Rankings of MENA countries } \\
\text { with available data }\end{array}$ & Score & Rank \\
\hline United Arab Emirates & 0.6397 & 103 \\
\hline Kuwait & 0.6318 & 105 \\
\hline Tunisia & 0.6266 & 107 \\
\hline Bahrain & 0.6217 & 110 \\
\hline Lebanon & 0.6084 & 116 \\
\hline Qatar & 0.6059 & 117 \\
\hline Algeria & 0.6052 & 119 \\
\hline Jordan & 0.6048 & 120 \\
\hline Oman & 0.5950 & 122 \\
\hline Iran (Islamic Republic of) & 0.5933 & 123 \\
\hline Syrian Arab Republic & 0.5926 & 124 \\
\hline Egypt & 0.5899 & 125 \\
\hline Morocco & 0.5767 & 127 \\
\hline Saudi Arabia & 0.5713 & 129 \\
\hline Yemen & 0.4603 & 134 \\
\hline
\end{tabular}

(United Nations, 2011, p.1) 
Figure 3 Social investment budgets by industry sector

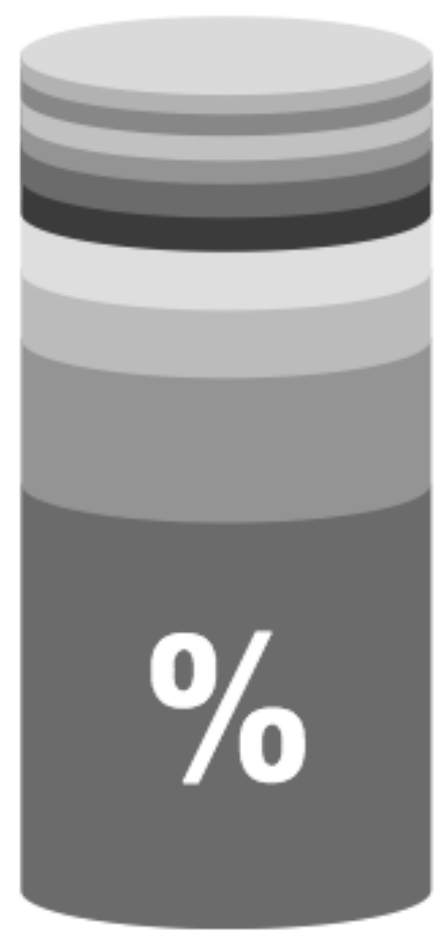

0,50 Chemicals \& synthetics

0,56 Telecommunications, electronics \& computers

0,62 Automotive

0,69 Oil \& gas

1,02 Food \& beverage

- 1,03 Finance \& insurance

1,82 Metals, mining \& engineering

1,89 Transport

4,60 Utilities

11,87 Pharmaceuticals

Base: 65 companies that report value of social investment and pre-tax profit, income or earnings.

Source: KPMG International, Sustainable Insight:

Unlocking the Value of Social Investment, May 2014 